\title{
Position of Historical Textures in Urban Development with a Glimpse to Qajar Garden Palace-Tehran
}

\author{
Maral Fayazi \\ Faculty of Arts and Architecture, Azad University-Yazd, Yazd, Iran
}

Email address:

Mfayazi_art@yahoo.com

To cite this article:

Maral Fayazi. Position of Historical Textures in Urban Development with a Glimpse to Qajar Garden Palace-Tehran. International Journal of Science, Technology and Society. Special Issue: Research and Practice in Architecture and Urban Studies in Developing Countries.

Vol. 3, No. 2-1, 2015, pp. 99-102. doi: 10.11648/j.ijsts.s.2015030201.29

\begin{abstract}
Throughout history, mankind has been able to use its architectural techniques in order to construct residential spaces for itself and leave worthy and remarkable relics. Iran has significant monuments, buildings and architectural works among which Garden has always been considered important in both cities and decorative architectural motifs and paintings. This study tries to identify main range of the garden of Qasr Palace and analyze reflections of urban developments.
\end{abstract}

Keywords: Qajar Garden Palace, Landscape Retrieval, Garden Museum, Qasr Jail, Urban Development, Qajar Palace

\section{Introduction}

By growth of Tehran, vast extra-fort gardens were included in the city. Constructed in 1834 by the order of Fathali Shah on a hill somewhere between Shemiran old road and Abbass Abad St., Qajar Garden Palace is one of these examples which became eminent for its vastness and glory. However, the palace was desolated roughly half a century later. Edifice of the garden was destroyed due to heavy rain and flood in 1905 . A jail was designed in the garden by Cossack officer Nikolai Markov after Reza Shah took power. Because of being old, rusty and also located in the middle of the city, the jail was closed in 2003. In 2007, according to the resolution of Tehran`s Islamic city council transformed into a cultural centre with a focus on History of Tehran and Islamic revolution. This place is used now as a garden-museum so that the garden in a new sense has created a form of garden which does not comply with the axiom of it. Usage of most parts have been changed and the garden is separated by two streets (Moalem St. and Shahid Ghodusi St.) and has military application.

\section{Location and Formation}

Looking at the texts and documents in which the garden is mentioned, one can understands that what is now called as Qajar garden palace is only a part of that vast historical garden. Comte de Sercey wrote in 1839: that is a summer house between the city and the mountain on the north of the city, which is called Qajar palace, and the former king often resided there, but it is totally desolated today and likely, it will become ruined soon.

This palace is located on a conical hill and there are beautiful gardens around it in which multiple streamlets (contemporary architecture, 124) (Figure 1.). Jean-Baptiste Eugène Napoléon Flandin who had come to Iran in the reign of Mohammad Shah Qajar (1840-1841) describes: "Fath Ali Shah has made a palace constructed a milestone out of Tehran which is called Qajar palace or Qajar throne" (contemporary architecture, 124).

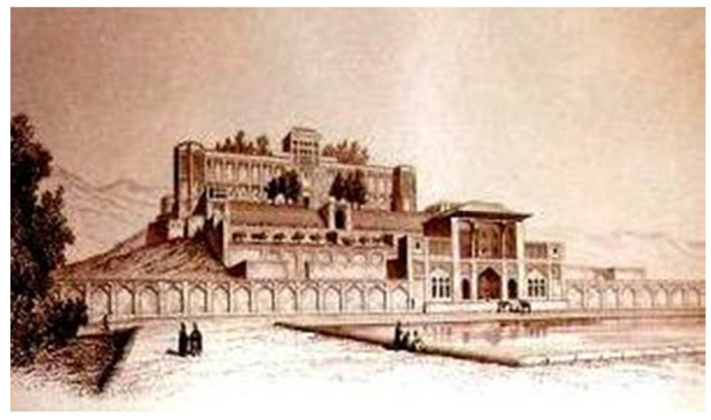

Figure 1. Qajar palace.

Madam Karla Serna (1877-1888) who lived during the reign of Nasser al-Din Shah Qajar has also wrote:"Qajar palace which is built like an amphitheatre on a hill overlooks other constructions which are built after that. This palace has a 
vast garden which is 600 meters long and 400 meters wide; and also possesses several wooded parallel streets" (contemporary architecture, 12).

\section{Historical Transitions}

This palace has been heeded during the reign of Fath Ali Shah Qajar but it was rarely used afterwards. In the reign of Nasser al-Din Shah Qajar (1831-1896) until the end of Mozaffar Al -Din Shah Qajar, qhazagh Khaneh camps were held in this place and the king went there once a year in order to see military parade.

Furthermore, Nasser al-Din Shah usually stayed in this palace during dusting up Golestan palace before New Year holidays. Destruction of Qajar palace commenced when Qajarid kings after Fath Ali Shah did not pay attention to this historical palace. According to Comte de Sercey no one resided in the palace in 1839 and tableaus which were mounted on the wall had become birds' nests started decaying (contemporary architecture, 124).

Jakob Eduard Polak has also mentioned to inadvertence to the garden that made great plane trees withered (Polak Logbook, P 83).

According to Karla Serna Nasser al-Din Shah did not like this mansion however he issued the order of repairing it as well as Negarestan and Lalezar palaces in 1851 (KarlaSerna Logbook, P 60). Donald Newton Wilber reported in his book "Persian Gardens and Garden Pavilions" that bricks and pieces of stones of main mansion of this garden were looted in 1950 in order to be used in adjacent buildings (Persian Gardens and Garden Pavilions, p 171).

In the reign of Reza Shah Pahlavi (the first Pahlavi, 1921-1941), the center for wireless telegraphy was established in Ghasr-e Ghajar village in Shemiran road. Markov jail (Shahrbani jail) was built in the southern lands of the palace and Reza Shah officially inaugurated that (Architecture of Nikolai Markov, P 92). Other changes include widening the road of Shemiran, establishment of the first radio station (1940), establishment of military facilities and changing the usage from garden to jail and military base. Available latest pictures of Qajar palace date back to 1946 (picture 2.) show that pavilion with the area of $70 \mathrm{~m}$ are disappeared.

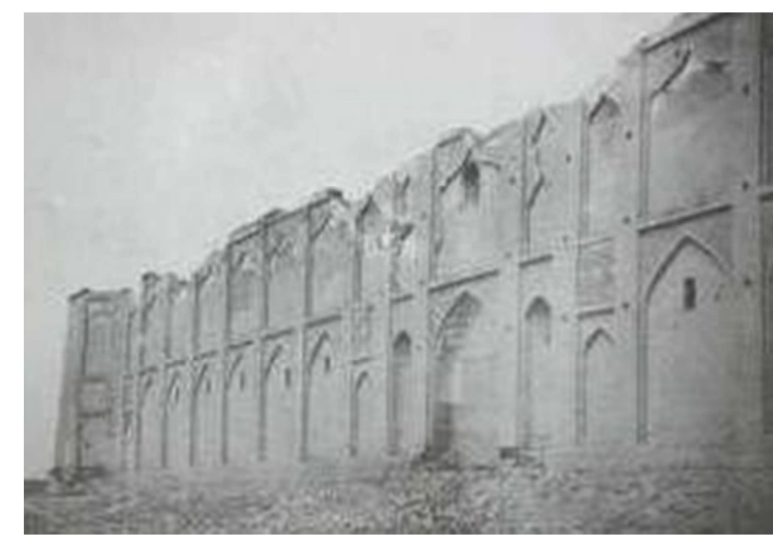

Figure 2. Available latest pictures of Qajar palace date back to 1946
In the reign of Mohammad Reza Pahlavi (1941-1979) two dining halls were added to the jail. From 1961 map of Abbas abad and lands which surrounded Qajar palace developed due to their proximity to Shemiran road as it was located between two urban cores. By establishment of post, Telegragh and Telephone Ministry in an area which belonged to the former Qasr village in 1970s, a suburban core in abbass abad district formed.

Since 1979 a complete urban texture with social and physical differences on both sides of Shemiran old road (Shariati St.) had formed. Because of proximity of both south and west parts of this residential texture to downtown, it has become similar to downtown core. Being located in the capital city in addition to other factors such as geographical location of the area, its landscapes and existence of Shemiran road are the reasons of formation of a summer residential area with palaces, and gardens in a place close to central core of Tehran. Furthermore, new rule requirements made this area being converted to a military location. Besides, large scale usages such as a hospital for army and teacher training college etc in the area led to a boom in the road and subsequently widening it.

\section{A glimpse to the Garden Architecture: Past and Present Time}

Donald Wilber quotes a person who had visited how it was created from the beginning: several parallel streets were created in which different kinds of trees such as poplar, willow, fruit trees and roses were planted (Persian Gardens and Garden Pavilions, p 171.). Karla Serna writes in her log book: This palace has a vast garden which is 600 meters long and 400 meters wide; and also possesses several wooded parallel streets. Too many roses, jasmine, different kinds of shrubs, as well as many Iranian famous peach and other fruit trees has created a charming complex (people and sites of Iran, P 61). Ernest Orsolle also writes: "the gardens of the palace which are separated by pools and creeks are constructed on terraced lands" (Le Caucase Et La Perse, P 34).

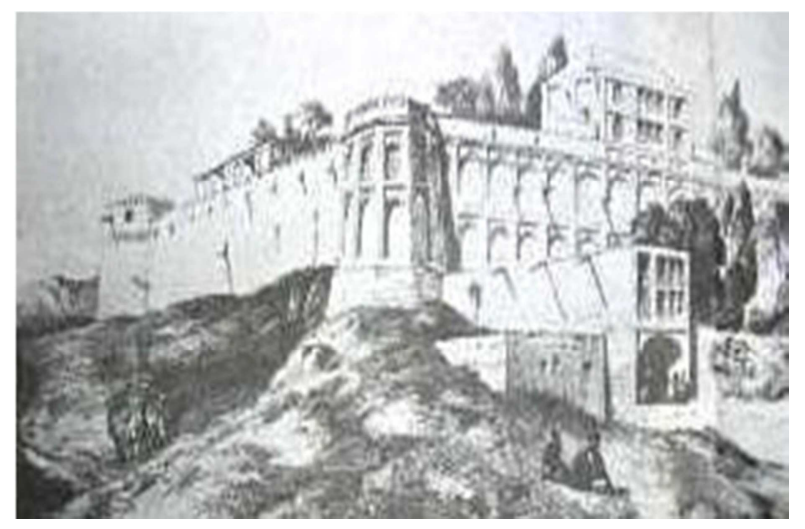

Figure 3. Qajar palace - demonstrates existence of aqueducts in the area.

Furthermore, a description about water supplies of the garden in the "Notes from private life of Nasser Al-Din Shah" 
demonstrates existence of aqueducts in the area (Figure 3.).Doost Ali Khan Moaye Al -Mamalek, author of this book has provided a detailed description of mansion of the palace and somehow has explained architectural geometry of it (Notes from private life of Nasser Al-Din Shah, P48).

Naser Najmi writes: "Interior design of the rooms like in most sumptuous buildings includes strange, simple and free-standing paintings of epic scenes of Iran which were mixed to images of Genghis Khan and Tamerlane (Figure 4.) (Tehran`s Dar Al-Khelafeh, P 126).

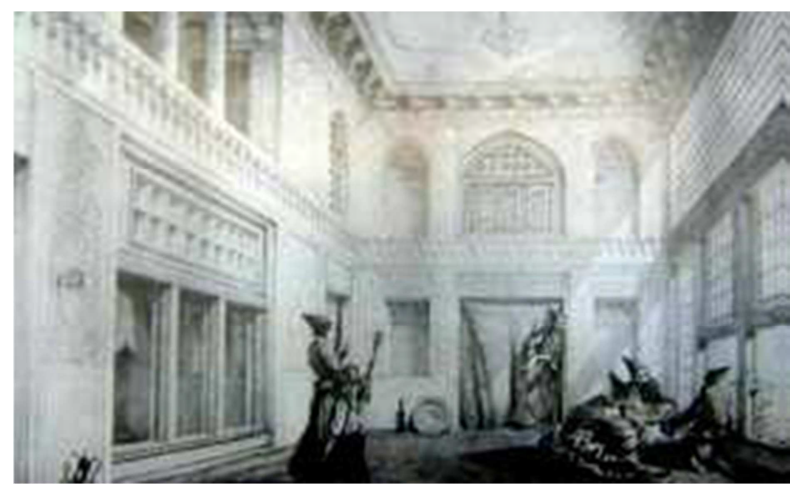

Figure 4. Qajar palace - Interior design of the rooms.

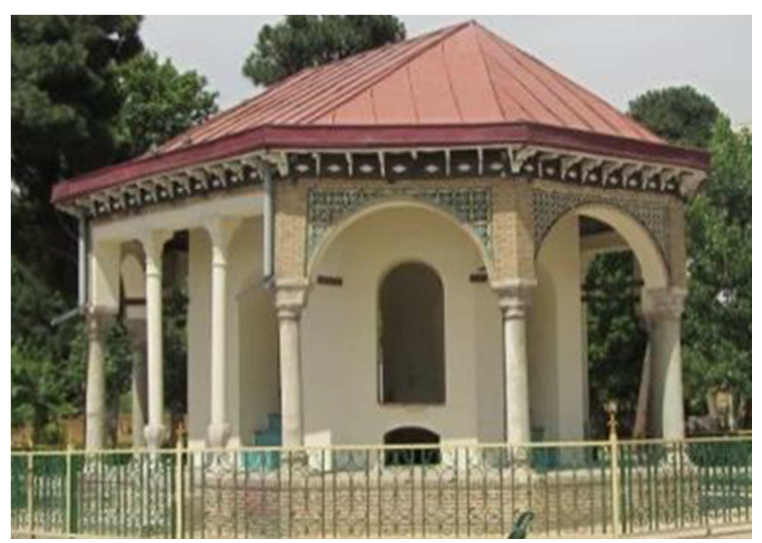

Figure 5. small summerhouse-2014, writer.

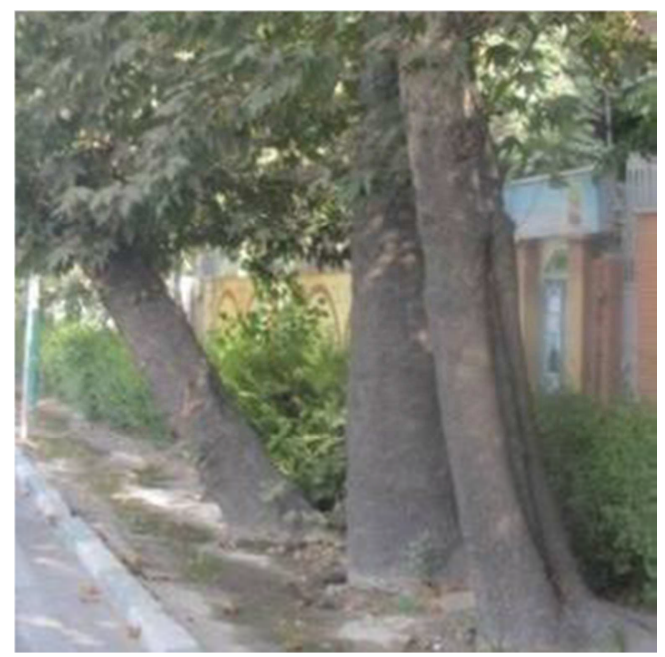

Figure 6. Old platans in Ghodousi street.

It is possible today to retrieve image of the garden based on historical documents end evidences such as description of Head and Pool house mansions by Ernest Orsolle.

We can also perceive that: the remained small summerhouse has major differences with the original one in terms of architectural structure and only evokes the memory of original summerhouse. In short, except buildings which belong to Pahlavid era, nothing remained. From the old garden, one can only see some old trees in some streets of the area (Figure 6.).

\section{Discussion and Conclusion}

The study shows that similar to other architectural spaces, gardens such as Ferdows Garden have undergone major changes because of diverse needs and time exigencies and unfortunately, urban development led to serious irreversible impacts on this historical space. One can find traces of most parts of these spaces only in the remained historical documents and evidences because regrettably many documents and evidences have been destroyed due to many reasons or are not available. We should make efforts to maintain and protect buildings limits and lands not only the buildings themselves so that perhaps survivors such as Qajar palace can breathe in the middle of a mixture of modern and historical textures easily. It is believed that in the current situation, neither the land nor the limits of palace is not respected and enormous buildings have surrounded the palace which have deprived us from the beauty of the remaining building.

\section{Acknowledgement}

The author would like to express her gratitude to Ms Sahar Khosravanian and Mr. Mehdi Heidari for their cooperation in this study.

\section{References}

[1] Amirbani, Masoud, 2009. Contemporary Architecture. Honar-e- Memari Gharn Publication.

[2] Moayer Al-Mamalek,2012. Doost Ali Khan, Notes from private life of Nasser Al-Din Shah. Nashr-e- Tarikh-e Iran Publication.

[3] Wilber, Newton,2011. Persian Gardens and Garden Pavilions. Translated by Mahin Dokht, Saba, Elmi-farhanfi Publication.

[4] Orsolle, Ernest, 2003. Le Caucase Et La Perse. Translated by Saeedi, Ali Asghar, Pazhooheshgah-e- Oloome- Ensani Publication.

[5] Najmi,Naser, 1977. Dar Al-Khelafeh of Tehran. Amirkabir Publication.

[6] Polak, Jakob Eduard, 1982.Polak Logbook. Translated by Jahandari, Keikavoos. Kharezmi Publication.

[7] Jaubert, Pierre Amédée Emilien Probe,1968. Voyage en Arménie et en Perse. Translated by Etemad Moghadam, Bonyad-e Farhang-e Iran Publication. 
[8] Serna, Karka, Karla Logbook. 1983.Translated by Samiee, Gholam Reza. Nashre no Publications.

[9] Safi Golpaygani, Ghasem, 1995. Pictures of old Tehran. Tehran university Publication.

[10] Shafeee,Bizhan, et al, 2005. Architecture of Nikolai Markov. Deed Publication.
[11] Farnahad Counsulting Enginners, upstream projects of zone7, 2009 , Tehran.

[12] Album House of Golestan Palace, 2014, Tehran. 